\title{
Note on the Function of the Spines of the Crustacean Zoœa.
}

\author{
By
}

W. F. R. Weldon, M.A.,

Fellow of St. John's College, Cambridge; Lecturer on Invertebrate Morphology iu the University.

\section{With Plate XVI.}

ANYONE who has examined the so-called "protective" spines of the various Zoæa larvæ must have been struck by their great tendency to develop in one straight line, parallel to the long axis of the body. Among the Macrura this is the case in the Zocea of Peneus, in the larva attributed by Claus to Hippolyte, and in the Galatheidæ. In the Brachyura the same result is attained in a slightly different way.

A comparison between the behaviour of those forms which are provided with long spines and those which arê devoid of them, will show clearly that these structures have at least one function which has not, I believe, been hitherto recognised.

The accompanying drawing was taken from a Portunid larva, seen obliquely from above while in the act of swimming. The larva is seen to lie upon its back, and to swim in the direction of the arrow by rowing itself along with its maxillipeds, exactly in the manner of two men sculling a narrow racing boat. Steering is effected by means of the tail.

The great majority of the Brachyurous larvæ which I have observed swim in this manner, though some of them do not lie upon their backs.

If a number of Decapod larvæ be placed together in a large glass ressel, the effect of these spines upon their swimming capacities is very manifest. Such a larva as the Portunid of the figure will swim in an absolutely straight line towards the light, moving with great rapidity, and neither changing his direction nor losing his equilibrium during a journey of several feet. Those larvæ without spines, on the other hand, such as Crangon or Palcemon, will make their journey their journey towards the light in a very different manner. Their 
progress will be in a succession of ill-directed spirals, and it will be accompanied by that peculiar rotation about the long axis of the body which is seen in larvæ whose locomotion is effected by means of ciliated girdles. And not only will all forward movement be thus indirect, but it will be impeded by frequent and apparently involuntary somersaults, after which each Zoœa will hang for a moment vertically in the water, as if to recover its sense of direction.

It is hard to avoid the supposition that this power of rapid and direct motion which accompanies the possession of long spines must be an advantage to its possessor ; but if this be the case, it is difficult to imagine the causes which have led to the abolition of such spines during the passage from the Peneus group to such forms as Orangon, Palcemon, \&c., which are numerous and widely spread, while their larvæ are devoid of spines and incapable of executing the rapid and skilful movements in question. 
Jour. Mar. Biol Assoc. Vol. I, Pt II.

Plate XVI.

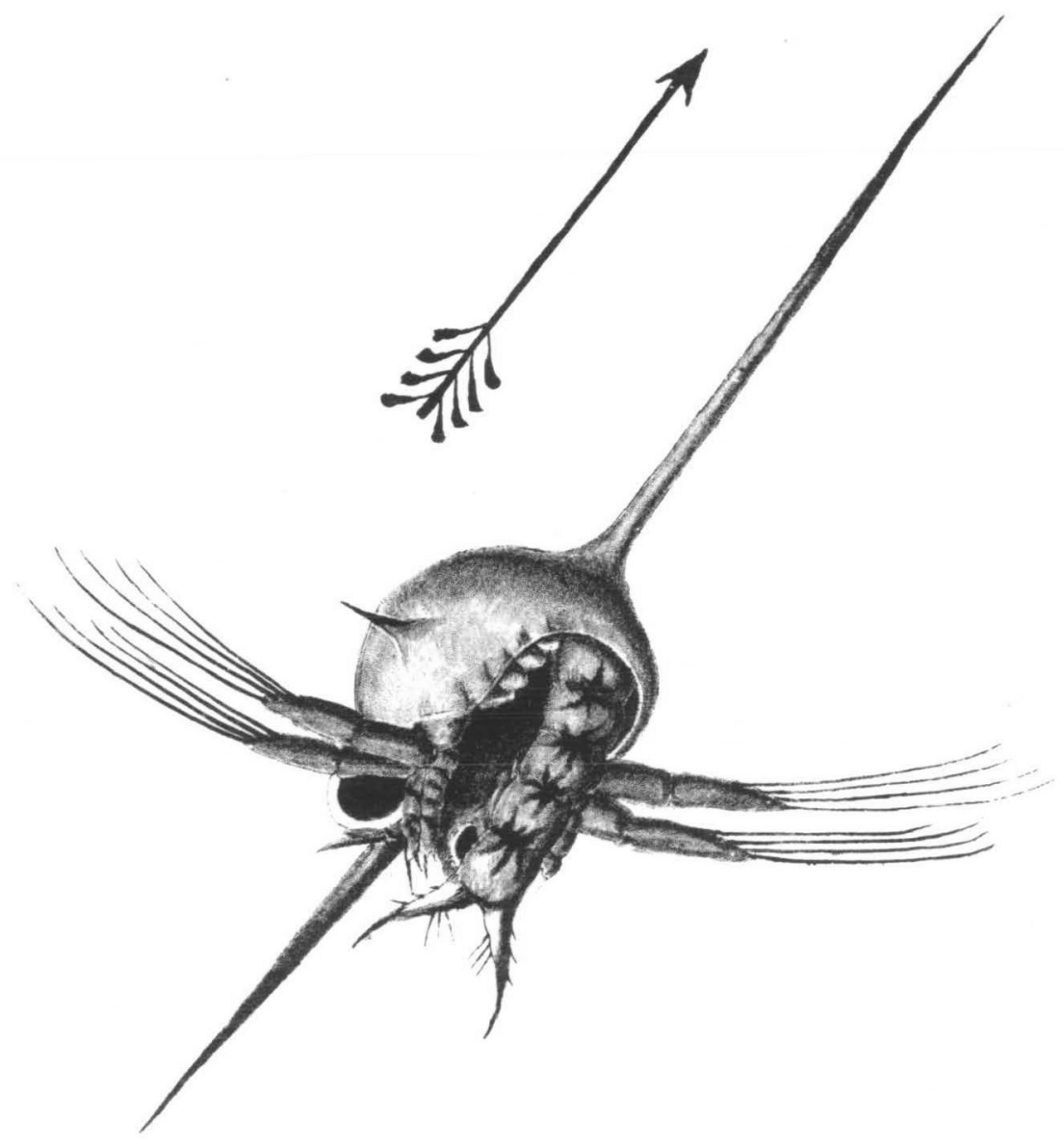

laticelo.

Downloaded from https://www.cambridge.org/core. INSEAD, on 29 Aug 2018 at 17:07:48, subject to the Cambridge Core terms of use, available at https://www.cambridge.org/core/terms. https://doi.org/10.1017/S0025315400057994 


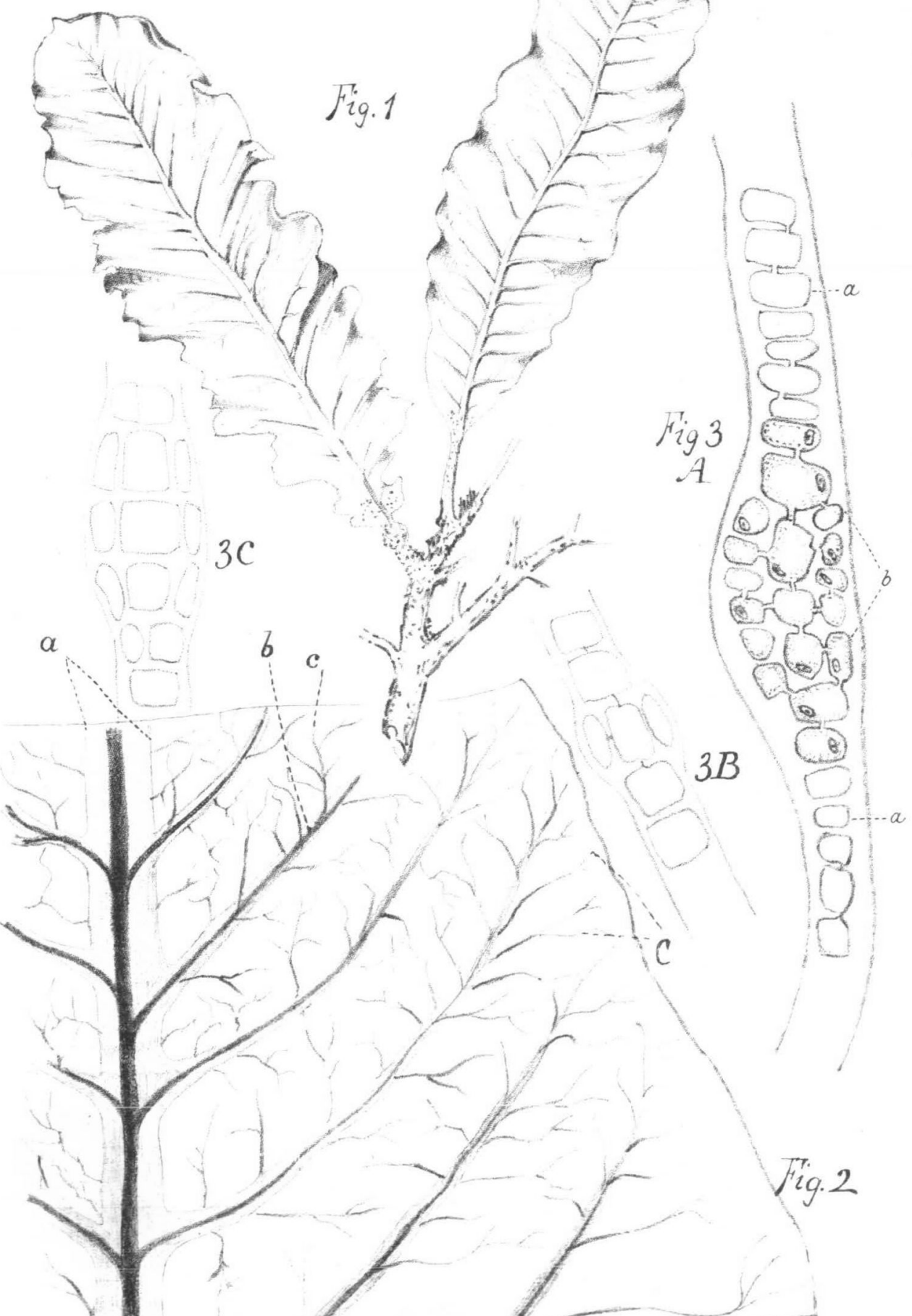

Downloaded from https://ww.cambridge.org/core. INSEAD, on 29 Aug 2018 at 17.07:48, subject to the Cambridge Core terms of use, available at https://www, cambridige.org/core/terms. https://doj.org/10.1017/S0025315400057994 